\title{
Is the Family System in Romania Similar to those of Southern European Countries?
}

\author{
Maria Castiglioni, Mihaela Hărăguş, Cristina Faludi, \\ Paul Teodor Hărăguş
}

\begin{abstract}
In his influential 1998 study, David S. Reher discusses historical differences between countries with strong and weak family ties. He focuses on the "Western World", comparing Italy and the Iberian Peninsula with Scandinavia, the British Isles, the Low Countries, Germany and Austria, together with North America. In this paper, we explore whether Romania, in Eastern Europe, can be characterised as having a strong family system, given the increasingly important role family has played for individual well-being following the end of the socialist regime. We observe a number of similarities between Romania and Southern European countries in terms of behaviours associated with "strong family ties", opinions on family care and mutual intergenerational support. Differences can be explained in light of Romania's economic and housing crisis. Overall, it is likely that the importance of family ties in Romania increased after the end of the socialist regime.
\end{abstract}

Keywords: Romania · Strong family ties · Living arrangements · Intergenerational support $\cdot$ Values and attitudes

\section{Introduction}

In his influential 1998 study on family ties, David S. Reher discusses historical differences between countries with strong and weak family ties. He focuses on the "Western World", comparing Italy and the Iberian Peninsula with Scandinavia, the British Isles, the Low Countries, Germany and Austria, together with North America. There has, however, been increasing interest in family models of former socialist states, especially following the enlargement of the European Union. Scholars such as Hajnal $(1965,1982)$ and Laslett (1983) originally described Eastern Europe and the Balkans (the countries East of the "Hajnal line", an imaginary line from St. Petersburg to Trieste) as characterised by a common historical pattern of early and nearly universal marriage and a "joint household" system. However, this homogeneous 
pattern has recently been questioned, as different aspects of family life, such as family structure, intergenerational relationships and obligations, and welfare systems are increasingly taken into account. Alain Blum (2001) argues that former socialist countries encompass a wide variety of family traditions, and that forty years of socialist regimes were unable to affect the culture of private family life. Recent macro-level descriptive analyses (which include the newer EU member states) have not been able to identify a uniform behavioural model East of the Hajnal line (Plakans/Wetherell 2005; Mandic 2008; Fokkema/Liefbroer 2008; Billari/Liefbroer 2010; Hoem et al. 2010; lacovou 2011; lacovou/Skew 2011), while existing comparative studies are more general and do not differentiate between groups of countries within the region (Saraceno et al. 2005). In her analysis of the structural determinants of leaving the parental home in Europe, Mandic (2008: 634), for example, finds that "the new member states from central Europe, in spite of geographical proximity and common recent 'communist' legacy, were found in all three [European] clusters, indicating a possibility of rather diverging developments".

Despite an increased interest in former socialist Europe, comparative data on family life remain scarce (Manning 2004). Important surveys on family choices and behaviours (e.g. Survey of Health, Ageing and Retirement in Europe (SHARE) and the Gender and Generations Survey (GGS)) still include a limited number of countries ${ }^{1}$ and results are often not comparable. In a similar vein, cross-national surveys on attitudes, beliefs and behaviour patterns (e.g. European Social Surveys and World Values Survey) may fail to match pertinent topics and countries.

This study adopts a different approach. We focus on one country at one point in time, so as to verify whether it fits a particular model. In our analyses, we refer to the framework of family ties and attempt to determine whether Romania, in the eastern part of Europe, can be characterised as having a strong family system, especially in light of the increased importance of the family for individual well-being following the end of the socialist regime. ${ }^{2}$

Identifying the specific role of family ties in Romania before and after the end of the Ceaușescu dictatorship represents a certain challenge. Before 1989, family ties were less visible due to the state's support of families and the independence the system granted to the youth. After 1989 it became unclear whether strong family ties were a preferred way of living, or rather a pragmatic and strategic response to the shock of the post-socialist transition and the unavailability or low quality of welfare services.

The second challenge concerns changes in living arrangements and union formation that are increasingly widespread in Romania - such as cohabitations and

1 No former socialist country was covered in the first wave (2004-05) of SHARE. In 2006-07, the Czech Republic and Poland were introduced, and in 2011 Estonia, Hungary and Slovenia. Unfortunately, Romania has not (yet) been included.

2 Similar processes have been observed in Albania, where the state assumed a primary role during the socialist regime, but the family regained its importance following the end of socialist rule (Danaj et al. 2005). The role of the family in post-socialist Bulgaria has been documented by Ghodsee and Bernardi (2012). 
births out of wedlock. Multiple interpretations of these behaviours are possible. From Reher's perspective, they are common in countries with weak family ties. Other authors (Hoem et al. 2009; Potârcă et al. 2013) suggest that they are signs of the diffusion of the Second Demographic Transition (SDT) in Romania. Alternatively, as they are especially visible among the weakest social groups, they may be a consequence of the political transition. Nevertheless, the question of how they interact with family ties in practice remains.

In the following, we compare Romania to Italy and Spain - two countries representative of strong family ties - as well as to other countries, both in West, North and East Europe, highlighting similarities and differences. We focus on family-related demographic behaviour, such as marriage and cohabitation, leaving the parental home, living arrangements of the young and the elderly, values and attitudes towards the family, and intergenerational support among family members. We use macro- and micro-level data from official databases and sample surveys. As far as possible, we select comparative data sources in order to strengthen our considerations.

\section{The Social Context of the Family in Romania}

The socialist regime in Romania (1947-1989) profoundly altered family relationships by imposing standardised life-paths. More specifically, this period was one of industrialisation - i.e. of the creation of a large industry sector - and the quasi-realisation of a full-employment programme. This also included the development of mass education, the nationalisation of agriculture (which turned farmers into wage earners) and a process of urbanisation. In 1960, 67.9 percent of Romanian inhabitants were living in rural areas, by 1990 this share had decreased to 48 percent. Education was seen by the regime as a means of developing an industrial workforce, consequently most high-school graduates were employed in industrial areas located in or near urban areas. Individuals from rural areas were given the opportunity to change their residence.

Young adults who grew up during the communist period had highly predictable and standardised paths of life. More specifically, they mostly originated from rural areas, left their parental homes to pursue secondary or tertiary education, and after graduation received jobs and housing, often sharing these with others of a similar social status. Marriage and the birth of a first child granted them the right to an individual dwelling. Massino (2010) observes that marriage was often a means of freeing oneself from communal living in the dormitories. More generally, the regime smoothed the transition to adulthood due to a lesser need for family involvement and support. Early departure from the parental home and independent living did not necessarily represent a personal choice for more independence, but was rather enabled and sometimes imposed by the social context, as graduates were forced to take up certain jobs.

A certain share of the rural youth, however, remained in their native regions, choosing instead a life-course that more closely resembled that of their parents. 
More specifically, they became wage earners in agriculture and, unlike their urban (or emigrational) counterparts, needed the support of their family, especially in terms of housing. Here the family system carried on the tradition of pre-modern rural families which is characterised by neo-local residence for newly formed conjugal couples (the new couple lives in an own residence without other relatives) and (extended) family support. Thus, the persistence of kinship networks (Blum 2001) can be observed across socialist Europe, largely in family structures where young adults or married couples continue to live with their parents.

Individuals who chose to pursue their education were supported through different policies (e.g. tax-free education or scholarships). Graduates then quickly entered the labour force, most of them being sent to places outside their native region. Such internal migrations and employment resulted in a greater physical distance between young adults and their parents, making family support both increasingly unnecessary and difficult to provide. Welfare supply was primarily the responsibility of the state, which in turn ensured the quasi-total absorption of young graduates into the labour force. Employment then provided social services, such as housing, family allowances, maternity leave, or other support (Popescu 2004).

In order to increase the number of working parents in the labour force, the state created a large network of childcare institutions. Mothers could thus immediately resume employment after birth and grandparents were not burdened with childrearing. Here, family ties did, however, continue to play an important role. For instance, grandparents often remained the primary providers of childcare due to the low quality or scarcity of these public services (Popescu 2004).

With regard to the elderly population, the introduction of a pay-as-you-go pension system and an increase in labour market participation following the establishment of the socialist regime greatly increased the number of pension receivers. Financial benefits reduced old age poverty as well as the need for support from the family. Individuals were thus no longer burdened with the responsibility of directly caring for the elderly, and were able to meet the requirements of the Family Code (1954), which stated that descendants have care obligations towards their parents (that could be paid in kind or in cash).

The system did not, however, account for special needs, such as sickness and old age disabilities. Here, state support was practically non-existent and the number of elderly care institutions was very small (such institutions were commonly called "asylums" and their image was very negative), so that sick and disabled elderly care became almost entirely the responsibility of the family.

The socialist revolution constituted a radical break from the past, and families were defined as the "depository of traditions" (Kerblay 1985: 564) or the "place where cultural traditions were perpetuated" (Blum 2001: 236). However, these reforms eventually lost their momentum and, after 1970, were overridden by "a regressive retreat from Marxist principles to conservative nationalism" (Massino 2010: 38). Such reverses in political discourse and in specific measures to outwardly preserve families - for example, the prohibition of abortion and restrictions imposed on divorce - (Inglot et al. 2011) affected family life. Nonetheless, after a period of flux, long-term behavioural trends continued (Blum 2001). 
After the fall of the communist regime in 1989, the life course of young Romanians became far less predictable due to the social and economic changes. With the state reducing its support (Ferge 1997) and instituting increasingly limited social policies (Popescu 2004), there was much uncertainty, anxiety and fear (Genov 1998). Graduation no longer ensured secure jobs and housing and employment rates dropped by 20 percent. Women in particular left the labour market and turned towards family care, minding their children and parents.

Parental leave, non-existent during the communist regime, was introduced in 1990. Public childcare, however, almost disappeared, and the importance of family support grew (Rotariu et al. 2012). Participation in early education (for children aged 3-6 years) increased from 72.3 percent in 2002 to 82 percent in 2012 (compared to the EU average of 93.2 percent in 2012). Owing to insufficient public provision, private childcare services emerged, but for the majority of the Romanian population the costs are prohibitive.

Young adults tended to stay in their parents' household longer due to socioeconomic insecurity. Thus, the importance of family support increased. Entrance into the labour market was delayed and became ever more difficult, reflected by a growing youth unemployment rate (under the age of 25). Individuals who chose to pursue higher education faced similar issues. Education was no longer tuition-free; from 2000 to 2010 approximately half of all students paid tuition (UEFISCDI - CNFIS 2014) at the same time state support for students was reduced dramatically. Following graduation, the transition into employment became increasingly difficult. The housing market also underwent a number of changes: home-ownership became predominant, the rental sector became almost entirely privatised and municipal housing was severely marginalised (Speder 2005; Mureșan et al. 2008). ${ }^{3}$ These changes were the result of several factors, including the selling of formerly public housing into private ownership soon after the fall of socialism, a sharp decrease in the construction of new dwellings and the share of construction from public funds, ${ }^{4}$ a decline in the purchasing power of the population during this transition period, combined with a spike in housing prices (Dan 1996, 2009). These factors meant that many families needed to extend the period of support for their children (Bezrukof) Foigt 2002), which made "leaving the nest" an important step for both children and parents, perceived as a fundamental shift towards adulthood.

By the end of the socialist regime, pensions amounted to 60 percent of the mean salary in Romania. By 2007, however, they had dropped to 36 percent, leading to increased poverty and a decrease in the standard of living. Institutions for elderly care emerged during this period, albeit in limited numbers and with continuing negative connotations. To this day, elderly care remains a concern for many families in Romania.

3 Law no. 61, 7 February 1990 (Decret-Lege $n r$ 61/7 Feb 1990) constitutes the act that initiated the privatisation of housing stocks; by 2002 only 1.25 percent were publically owned. Moreover, that same year, 93.2 percent of dwellings occupied by one family were occupied by their owners (2002 Census).

4 Public funding accounts for 2 percent of all housing stock in 2000 (Dan 2009). 


\section{Family formation}

\subsection{Departure from the parental home}

According to Reher (1998), countries with weak family ties are generally characterised by an early departure of youth from the parental home, as they seek to start their adult lives and achieve economic independence. Housing is often shared with friends or colleagues who are in the same stage of their lives. Years may pass until marriage. In countries with strong family ties, patterns of leaving the parental home are quite different: young people continue to live with their parents even after they have found a job, and their final departure tends to coincide with marriage.

The European Commission Report on Youth (2012, with 2010 data) shows strong disparities across countries regarding the average age at leaving the parental home, with clear clusters of countries (Table 1). In Finland, the Netherlands and France, both women and men leave the earliest compared to the rest of Europe, at an average age of 20.9-22.9 for women and 22.9-24.9 years for men. In Eastern and Southern European countries, the average age is 25.0-27.9 years for women and 28.0-30.9 years for men. Italy stands out with the highest age for women, 28.0-30.2 years, which is very close to that for men. Although the age at which young adults leave the parental household has remained quite stable over time, since 2005, there are marked differences across countries (European Commission 2012). For instance, Eastern European countries - such as Bulgaria, Hungary and Romania - have seen substantial increases, particularly when looking at men in Romania.

Such differences are mainly due to a lack of financial resources and affordable housing (Eurostat 2009). Studies have associated a delayed departure from the parental home in Southern and Eastern European countries with high levels of unemployment and low wages of young people, coupled with scarce affordable housing (Aassve et al. 2007; lacovou 2001). This makes the parental home a protective shelter from economic hardship.

In Romania, a large proportion of individuals aged 15-30 cite "constraints" as the primary reason for staying with their parents for a longer period of time, thus confirming - in a subjective manner - what has been described above (Section 2). More specifically, 40 percent state that they cannot afford to move out and 37 percent report that affordable housing is scarce (Eurostat 2009). These figures lend support to Mureșan's (2007) affirmation that in recent years, "[Romanian] youth are not independent in a greater percentage nor earlier in life" (2007: 17) compared with socialist times. As described above, during the socialist era, youth independence was facilitated and supported by the state, but this is no longer the case. With increased difficulties in finding separate accommodation and the worsening economic situation, young people increasingly choose to prolong the stay in their parental homes until marriage, when the newly formed couple receives (financial) support from their families, relatives, or friends for the purchase of a dwelling (Mureșan 2007, 2012a): neo-local family formation is encouraged, and wedding guests contribute money to help the young couple buy a home or apartment. This financial help is a form of intergenerational support, and the same help is returned, usually to the 


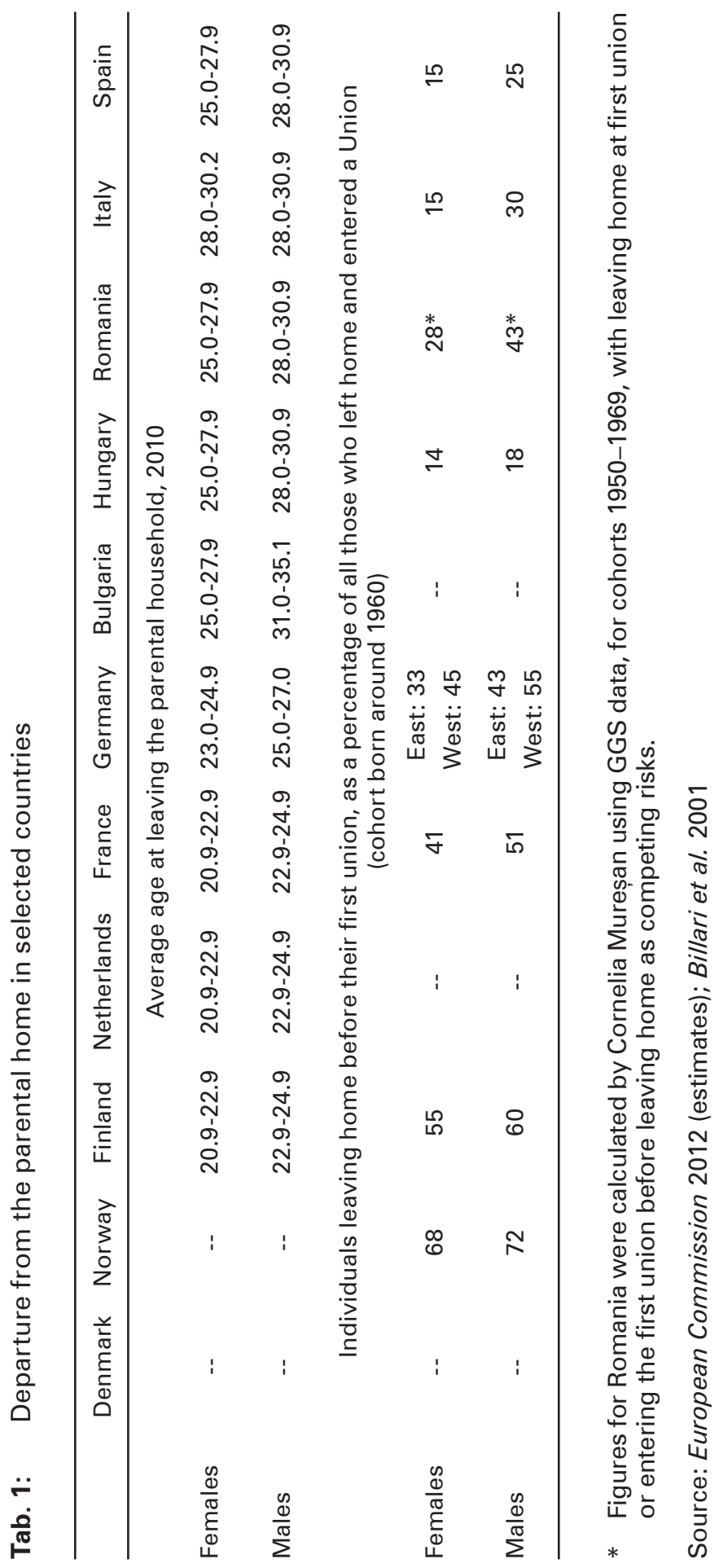


guests' children. To live independently of their parents, young people must be able to afford an expensive apartment (especially in large urban areas) or an equally high monthly rent (Ahmed/Emigh 2005, for Eastern European countries). Parents with financial resources help their children buy a home or apartment; however, such help is usually associated with marriage (Mureșan 2007, 2012a). This can be seen as a means of imposing certain life patterns or as a way to maximise financial help, even from in-laws. Young professionals with high incomes can afford renting a house or an apartment and living separately from their parents before entering marriage. However, this is not the case for all young adults, even for those who have entered the labour market (Mureșan 2007, 2012a).

Some youth in Romania chose to pursue higher education in a different city living neither with their parents nor independently. These young adults typically receive financial support from their parents (Mureșan 2007, 2012a) and visit them on a regular basis (distance permitting). If, after graduating, they do not find a job in the city, they usually return to the parental home. When parents cannot meet the costs of education, youth will often take up a job to support themselves, and contributions from parents take the form of different goods (such as food). This context substantially differs from the previous regime, when the state assisted youth in pursuing their studies through scholarships that also covered accommodation expenses.

In conclusion, many economic constraints affect the path of leaving the parental home. However, young people increasingly choose to relate to their family, as in Italy and Spain, rather than to follow alternative models (such as leaving early and share an apartment with friends) more similar to those of young people in Northern or Western countries.

Differences in leaving the parental home are thus expressions of variances in social norms (Aassve et al. 2007). While in Southern and Eastern European countries, departure most commonly coincides with marriage, in Northern countries most of the young people leaving their parental homes do so to live alone or with friends. It is, however, noteworthy that the percentages of men and women born around 1960 who left the parental home before the formation of a first union were higher in Romania compared to other Eastern or Southern countries (Table 1). These cohorts made this transition mainly during the socialist regime, reflecting the role of the state in facilitating departure from the parental home for the pursuit of university education and in providing support for living independently (as described in Section 2). After 1989, the state reduced its support and levels of leaving the parental home before the first union dropped. A comparison of data for the period of 19801989 to that of 1996-2005 shows a decrease from 27 percent to 22 percent for women, and from 38 percent to 33 percent for men (Mureșan 2007). Simultaneously, the percentage of those forming a first union while still living in the parental home increased, especially for men: 13 percent to 14 percent for women and 23 percent to 28 percent for men (Mureșan 2007).

According to Aassve et al. (2007), educational infrastructures play an important role in shaping European differences. For instance, in Scandinavian countries and in the UK, young people are expected to leave the parental home to pursue their tertiary education. By contrast, in Italy, education policy aims at ensuring geographi- 
cal accessibility of universities, thus enabling the youth to continue living at home during their studies. In post-socialist Romania, universities are similarly spread throughout the country, potentially having the same effect on leaving the parental home, but unlike in Italy, this diffusion was not explicitly aimed at assisting the youth in undertaking higher studies while living in their parental homes.

These patterns of behaviour of the Romanian youth are similar to those of their counterparts in other Southern and Eastern European countries. The collapse of the socialist regime in Romania reduced resources and opportunities for independent youth living. Departure from the parental home thus came at an increasing age, and was commonly characterised by a transition to adulthood through marriage. In the face of economic constraints, families play a crucial role in shaping the conditions under which children are able to live independent lives.

\subsection{First union and first birth}

According to Reher (1998: 215), "societies with strong families tend to have greater social cohesion"; a low incidence of both cohabiting non-married couples and nonmarital childbearing seem to characterise such societies. Accordingly, it is important to examine whether the decrease in marriages in Romania was accompanied by an increase in non-marital unions (cohabitations), and whether women or couples choose to maintain this alternative living arrangement throughout their life course or shift to marriage when it comes to childbirth and raising children.

According to Hoem et al. (2009) and Mureșan (2007, 2012a), marriages not preceded by cohabitation have decreased in Romania since the 1990s, while cohabitation as a first or preliminary form of relationships has steadily grown. For the period of 1996-2005, the proportion of women who cohabited before the age of 40 was 35 percent, compared to 20 percent for the period of 1980-1989 (Mureșan 2007). The proportion of non-marital births also increased steadily after the fall of the Berlin Wall, from 17 percent in the early 1990s to 31 percent in 2012 (Table 2). Do these figures indicate weak family ties in Romania? To answer this question, we compare the spread of these behaviours to that observed in other European countries (Table 2).

In the 1990s, the proportion of non-marital births in Romania was already relatively high, particularly in comparison to Bulgaria and Hungary in Eastern Europe, and Germany and the Netherlands in Western Europe, although still much lower than that observed in Northern Europe. In the following years, the number of births out of wedlock spread quite rapidly in the countries mentioned above: in 2012, they reached the percentages of the Northern countries. Romania, on the contrary, has maintained relatively stable levels over the last ten years, comparable to those observed in Italy and Spain.

Recent investigations have, however, shown that marriage remains the preferred context for childbearing in many European societies, particularly in Eastern Europe. Comparing data from the Generations and Gender Survey and other comparative surveys for 11 European countries, Perelli-Harris et al. (2012) investigate how cohabitation as a setting for childbearing and childrearing has differed by country and 
year. The records show an increase in the percentage of women who cohabited at the beginning of their fertile unions in all countries, although at different levels: from 1995-2005, this proportion amounted to 18 percent in Italy, 29 percent in Romania, 46 percent in Hungary, 77 percent in Bulgaria, 78 percent in the Netherlands, and 90 percent in France and Norway. Of these countries, Italy and Romania recorded the lowest shares of women who continued to cohabit at conception, birth, or three years after birth (Table 2). Thus, in Italy, Romania and Hungary marriage continues to be the preferred context for childbearing and childrearing, and the pattern of conception during cohabitation followed by marriage has persisted (Perelli-Harris et al. 2012). This suggests that in Romania and some other Eastern countries, many non-marital conceptions must be unplanned pregnancies.

According to Reher's framework, cohabitations and births out of wedlock in Romania might be interpreted as indicator of weak family ties. However, other studies suggest that women living in rural areas with low levels of education and a low socio-economic status cohabit and/or give birth outside marriage more frequently than urban, well-educated and financially successful women (Rotariu 2009; Rotariu et al. 2012; Hărăguş 2008, 2010; Oaneş-Faludi/Hărăguş 2009). Differences within Romania do not support a classic interpretation of the process of diffusion of new demographic behaviours. Neither is the sudden increase in the 1990s, and stagnation of (since 2004), non-marital births in Romania necessarily a symptom of a transition towards a value system that is typical for late or post-modernity, as such a transition would have continued, and not suddenly halted. Rotariu et al. (2012) argue that such a pattern is, rather, the result of a revival of certain behaviours that developed over the past centuries in Romania. Moreover, non-marital births are mostly viewed as socially acceptable behaviour in Romania, at least in certain communities. ${ }^{5}$

In conclusion, patterns of family formation in Romania differ from those in Northern and Western Europe. The slow increase of cohabitation and non-marital births is more likely to be the result of economic deprivation than a sign of weakening family ties.

\section{$4 \quad$ Living arrangements}

Reher (1998) considers that in contexts with strong family ties, the family takes on many roles (which are largely performed by the state in northern European countries), such as support for the needy and vulnerable. Although everywhere in Europe parents love their children, the expressions of this love vary (Reher 1998). While in regions with weak family ties, young people are encouraged to leave their parental homes early and build their lives on their own, in regions with strong family ties, the

5 Kok (2009) observes high levels of births out of wedlock around 1900 in provinces that form present-day Romania and associates these results with the region's family system, arguing that the present-day context of cohabitation and non-marital childbearing seem to be a return to past traditions. 
family is called upon to protect its members against the difficulties resulting from social and economic hardship. A similar behaviour characterises relationships with the elderly: families with weak ties seek to prolong their independence and typically turn to institutional help when no longer possible; for families with strong ties, the need to provide direct familial support for the elderly is seen as an obligation.

Greater individualism or solidarity can shape family structure and preferences for nuclear or extended families. Distinctions between regions with weak and strong family ties seem to reflect historical differences in family systems. This section focuses on patterns of living arrangements of young adults (20-34 years) and the elderly (65 years and above), as well as on attitudes towards the living arrangements of the elderly. We consider a high proportion of people living alone as an indicator of weak family ties and co-residence of multiple generations as an indicator of strong ties. Co-residence is an important mechanism in the social protection of the elderly and plays a crucial role in poverty alleviation (Palloni 2000; Lyberaki/Tinios 2005).

\subsection{Living arrangements of young adults}

Data on the living arrangements of young adults show important differences across countries (Table 3), highlighting a strong dichotomy between North and West Europe on the one hand, and South Europe on the other. Most of these differences can be linked to varying age patterns when leaving the parental home. Romania, Bulgaria, and Hungary form a distinct group in which a high percentage of young men, and a lower percentage of women live with at least one parent. The proportion of young adults living in an extended household is comparatively high in Eastern Europe. ${ }^{6}$

While the literature shows that such behaviour is associated with strong family ties in Southern European countries, two elements should be noted with regard to Eastern Europe and the Balkans: there is a historical pattern of family formation with a high incidence of extended or multigenerational households (Hajnal 1982; De Jong Gierveld et al. 2002; De Jong Gierveld et al. 2012), and a challenging housing situation in terms of availability and affordability (see Section 3.1 above; De Jong Gierveld et al. 2002; Robila 2004; De Jong Gierveld et al. 2012).

With specific regard to the extended household hypothesis, Kaser (1996) conducted a more detailed examination of households and families in the Balkans and revealed that a "neolocal-nuclear household formation system" is characteristic of Romania: upon marriage, boys traditionally received an equal share of land when leaving the parental home to set up separate residences. The youngest (or the old-

6 We further investigated this issue for Romania and Italy using individual-level data from the 10 percent samples from national censuses conducted in 2001 for Italy and in 2002 for Romania, made available by the Minnesota Population Center (IPUMS-International). This provided an in-depth understanding of co-residence with one's parents, which we define as living in the same household with at least one parent or one of the spouses' parents. Data confirm a high proportion of married children living with their parents in Romania. lacovou and Skew (2011), who include the new EU member states (besides Malta) in their analyses, also confirm these results; Estonia is the only exception among the former socialist countries. 
est) child remains with the parents (Kaser 1996: 381). As such, intergenerational co-residence is not a traditional pattern. In addition, a small proportion of complex or multigenerational households were observed in other countries (Kaser 1996; De Vos/Sandefur 2002, quoting Todorova 1996, for Bulgaria). This contradicts the idea that Eastern Europe and the Balkans are a homogeneous region with a high prevalence of extended households and moreover, the nuclear family had been the predominant family model in Romania.

The second explanation suggests that economic difficulties and uncertainties may increase co-residence (/sengard/Szydlik 2012), although in former socialist Europe an important factor is the housing crisis that emerged after the fall of the communist regime. Thus, families use household composition as an economic strategy to pool limited financial resources, especially during periods of economic strain and transition.

Ahmed and Emigh (2005) tested these two hypotheses as explanations for household composition (extended/co-residence versus nuclear) in post socialist Eastern Europe. They found that extended households represent an adaptive strategy for the poor, especially in countries where the post-socialist transition to a market economy was slow and difficult, such as in Romania, Bulgaria, and Russia. In these countries, one possible explanation for the increased spread of co-residence may be the extremely high costs of housing, exacerbated by privatisation.

In conclusion, the proportion of young adults living alone or with a partner in Romania strongly depends on their age at leaving the parental home. Moreover, the high incidence of intergenerational co-residence in Romania appears to be a result of an adaptive strategy rather than of preferences. Nevertheless, the response to economic difficulties is parental support, confirming the importance of family ties in the process of family formation.

\subsection{Living arrangements of the elderly}

Based on the 2001 national censuses (comparative data for the census round of 2010/11 are not yet available), Eurostat data on living arrangements for the elderly (65 years and older) show clear differences between Northern or Western and Southern European countries. For instance, Southern European countries recorded lower proportions of individuals living alone and higher proportions of co-residence with children (Table 4). Romania can be found somewhere in the middle, with the proportion of individuals living alone more similar to Italy and Spain than to Northern or Western countries, and co-residence with children higher than in France and Finland but lower than in Italy and Spain.

Census data have an important advantage compared to survey data: they do not only account for people living in private households, but also for those in institutional settings. Table 4 shows that the proportion of elderly individuals living in institutions is higher in Northern and Western Europe than in Southern and Eastern European countries. Among those aged 65 years and above, 0.4 percent were living in institutions at the time of the 2002 Census in Romania. This proportion was also comparably low in Italy and Spain (2.1 percent and 2.3 percent, respectively), as 
Is the Family System in Romania Similar to those of Southern European Countries? $\quad$ - 71

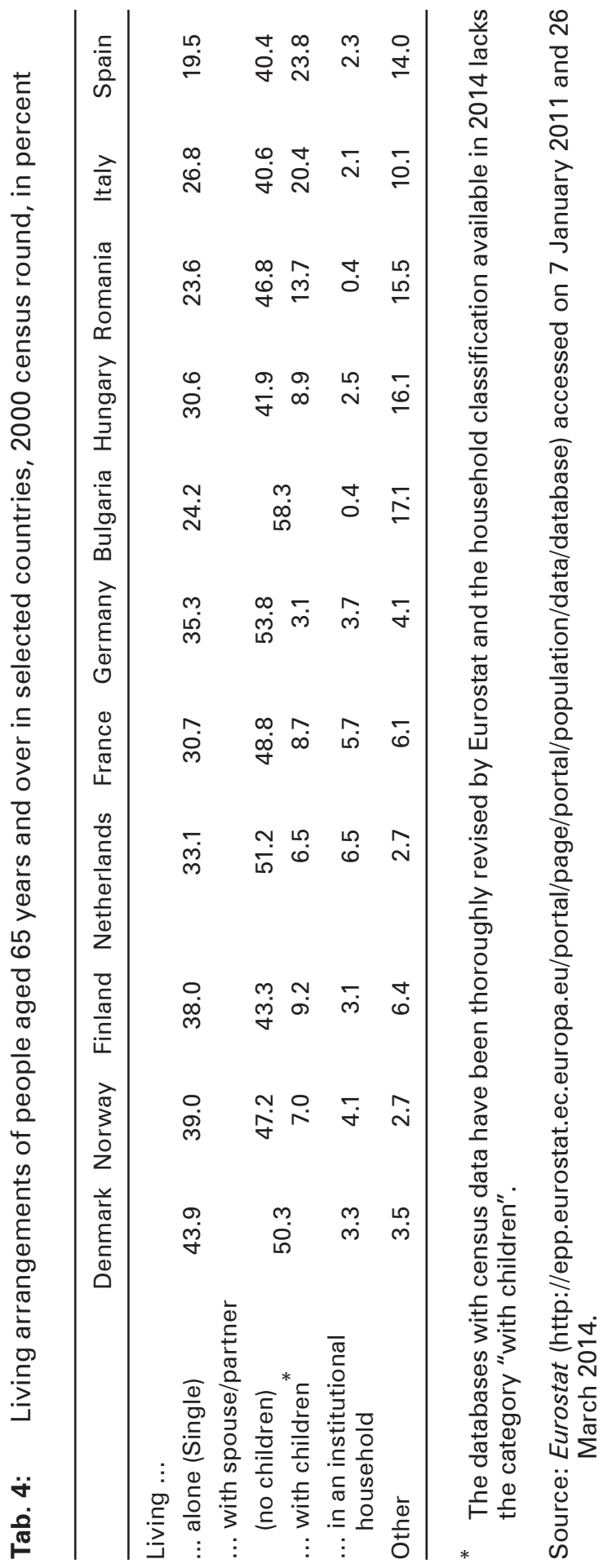


well as in Bulgaria and Hungary (0.4 percent and 2.5 percent, respectively). These results reflect attitudes regarding preferred living arrangements for the elderly in need (see Section 4.3).

The residual category, "other," is vague and does not impact the broader observable typologies. The label mainly concerns alternative forms of extended families, such as elderly individuals living with other people in a shared house or flat. Nevertheless, Romania, Bulgaria, and Hungary show the largest diffusion of several forms of co-residence, similar to patterns observed in Italy and Spain. ${ }^{7}$

These results for Northern, Western and Southern European countries are in line with the literature in the field. Co-residence has been documented to be the highest in Mediterranean countries (lacovou 2000a, 2000b; Tomassini et al. 2004; Kohli et al. 2005; Hank 2007), while living alone or only with a partner have been found to be most prevalent in Sweden, Denmark, and the Netherlands (lacovou 2000b).

Using data from the SHARE survey, Kohli et al. (2005) document a weak-strong family dichotomy corresponding to a northern-southern distinction in the family structure of the elderly. lacovou and Skew (2011) extend their analysis to new EU member states and find similarities among Southern and South-Eastern countries, including Romania. Other post socialist countries follow a more heterogeneous pattern (Engelen/Wolf 2005; lacovou/Skew 2011). Data from the GGS (authors' calculations) similarly support the idea that in Eastern and Southern Europe, rates of intergenerational co-residence are higher than in other industrialised European countries. In Italy and Russia, the percentage of parents aged 50 and over who coreside with at least one child exceeds 50 percent, followed by Bulgaria, Hungary and Romania, with rates between 40 percent and 42 percent. The percentage of parents living in the same household with at least one child is much lower in Western and Northern Europe: 27 percent in France, 24 percent in Germany and Norway, and below 20 percent in the Netherlands. A similar ranking results from an analysis of women aged 35-44 years with children who co-reside with their own mother, although at lower percentages.

Romania thus exhibits high proportions of elderly who co-reside with their children or other relatives and correspondingly low proportions of elderly who live alone or in institutions. These shares are similar to those observed for Southern European countries but different from those measured in Western and Northern Europe. These proportions have increased in Romania compared to the 1992 census (De Vos/Sandefur 2002: 30; Table IV). As is the case for the living arrangements of young adults in Romania, the high and increasing proportion of elderly co-residence with their offspring and other relatives may be associated with housing constraints.

7 IPUMS census data were also employed to study co-residence with children in Romania and Italy, regardless of their marital status and age. Results show that the overall proportion of elderly living with children is more similar than that shown in Table 4. More specifically, levels are somewhat higher in Romania than in Italy (32.2 percent compared to 28.9 percent). In Romania this phenomenon is more common among the elderly who are not married (mainly widowed), while in Italy it is more frequently observed among the married elderly (likely due to children's delayed departure from the parental home). 
Here too, co-residence is more of an adaptive strategy than a preferred choice, though again underlining the fact that people rely heavily on family support.

\subsection{Attitudes towards living arrangements}

As argued above, higher proportions of co-residence of the elderly and their children in Southern Europe, as well as in Romania, are indicative of positive attitudes towards intergenerational care.

Results from the Eurobarometer surveys (Alber/Köh/er 2004) confirm that Romanians consider themselves responsible for the care of their parents if they are no longer able to live independently. A total of 68 percent of Romanians prefer that their parents co-reside with them, less than 1 percent prefer moving their parents into an institution or a nursing home (Table 5). Other results on the perception of future responsibilities regarding elderly care in Romania similarly show that the proportion of people who advocate extended family responsibilities is much higher than the proportion of those who reject them. In some Northern countries, on the other hand, the proportion of those who reject these responsibilities is even higher than that of those who support them (Table 5). Here, it is worth noting that Nordic countries have the highest percentages of elderly living alone or in institutions (Table 4).

The results for Romania described above are similar to those observed in other Southern and former communist countries. As Tomassini et al. (2004: 32) state, "the contrasts in attitudes between Northern and Southern European countries mirror the contrast in solitary living among their older populations". This assertion is similarly applicable to Romania.

Alber and Köhler (2004) outline a summarising picture of the living arrangements of the elderly in Europe, and show that European countries cannot be treated as a homogenous group. Using simple classification analysis, they characterise the group of Scandinavian countries as having a preference towards institutional care (high support of institutional care, compared to extended family responsibilities). A second group of countries, Southern European countries, shows a preference for family models (higher support of extended family responsibilities, compared to formal institutional care). Western European countries fall somewhere in between. Preferences in Eastern European countries and the Balkans are similar to those in Southern European countries with respect to caring for one's parents. Alber and Köhler (2004: 76) conclude that "there is little doubt that the family support model will become strengthened after [the] enlargement" of the European Union. 
Tab. 5: Attitudes towards the living arrangements of elderly people in need, in selected European countries. Preferred type of care for parents (col. 1 and 2); agreement with a higher personal involvement in elderly parents support (col. 3)

\begin{tabular}{lccc}
\hline & Preferred type of care for own parents & $\begin{array}{c}\text { Percentage point difference } \\
\text { between } \\
\text { and those rejecting higher } \\
\text { family responsibilities }\end{array}$ \\
\hline Denmark & 10.9 & $\begin{array}{c}\text { Nursing home } \\
(2)\end{array}$ & $(3)$ \\
Sweden & 11.6 & 32.8 & 11.7 \\
Finland & 17.4 & 43.0 & -17.2 \\
Netherlands & 15.5 & 17.1 & -2.2 \\
France & 37.5 & 35.5 & -6.6 \\
Germany & 48.9 & 15.1 & 15.6 \\
Bulgaria & 62.3 & 11.4 & 39.5 \\
Hungary & 58.6 & 4.8 & 80.4 \\
Romania & 67.7 & 4.5 & 74.4 \\
Italy & 59.0 & 0.9 & 82.6 \\
Spain & 80.7 & 1.9 & 75.5 \\
\hline
\end{tabular}

Source: Col. 1,2 Alber/Köhler 2004: 75, Table 24: Answers to the following question: "Let's suppose you had an elderly father or mother who lives alone. What do you think would be best if this parent could no longer manage to live on his/her own?"

Col. 3 Alber/Köhler 2004: 67, Table 21: Percentage point difference between those advocating and those rejecting family responsibilities for higher elderly care. Answers to the following question: "If in the future, working adults would have to look after their elderly parents more than they do nowadays, would you say that this would be rather a good thing or rather a bad thing?"

\section{$5 \quad$ Intergenerational solidarity}

In all countries - irrespective of strong or weak family ties - intergenerational reciprocity is relevant even if perceived quite differently (Reher 1998). Several authors argue that proximity and parental support are related to the strength of intergenerational ties, as well as to a welfare system which does not encourage individual autonomy (Reher 1998; Micheli 2000; Dalla Zuanna 2001; Dalla Zuanna et al. 2007). With this in mind, proximity and support can be used as proxies for the strength of such ties, in the sense that different proximity and support patterns correspond with different intensities of family ties (Santarelli/Cottone 2009). Living near to one another facilitates contact and support. The more frequent familial interactions are, the easier it is to give and receive support as well as to identify possible needs. Contact frequency is sometimes seen as a form of support in itself because it satisfies a social need (Fokkema et al. 2008: 11, 19). 
Recently, international comparative surveys such as the GGS and SHARE, have provided useful information for investigating the proximity and frequency of contact between parents and their adult children. Unfortunately, the two surveys differ in the formulation of their items and in sample composition. Comparable data for Romania are not reliable and comparative results are thus too uncertain.

The surveys do, however, measure attitudes towards family care obligations. The formulation of items was not identical, therefore percentages may reflect slightly different aspects. However, variance among countries is very strong and the results provide a general picture of the profound differences between countries (Table 6 and 7).

In terms of opinions, Romanians have strong traditional attitudes towards elderly care, as well as towards the care of children and grandchildren (Mureșan 2012b). Many believe that the family network should be the main provider of practical help. The reverse, however, is thought of financial support: society, and not the family, should take the primary role in providing monetary support for the elderly, and adults with children who cannot afford a minimum level of subsistence (Table 6). Generally, Romanians also have strong views concerning grandparents' support towards their adult offspring: grandparents should care for their grandchildren if their parents are unable to do so and should offer financial support if and when their

Tab. 6: Attitudes towards the responsibility of family and governments/society to care for the elderly, in selected countries, percentages per 100 respondents aged $50+$

\begin{tabular}{|c|c|c|c|c|c|c|}
\hline & \multicolumn{2}{|c|}{$\begin{array}{l}\text { Household help for } \\
\text { the elderly in need of } \\
\text { assistance }\end{array}$} & \multicolumn{2}{|c|}{$\begin{array}{l}\text { Personal care for the } \\
\text { elderly in need of } \\
\text { assistance }\end{array}$} & \multicolumn{2}{|c|}{$\begin{array}{l}\text { Financial support for } \\
\text { the elderly in need of } \\
\text { assistance }\end{array}$} \\
\hline & $\begin{array}{l}\text { Totally/mainly } \\
\text { the family }\end{array}$ & $\begin{array}{c}\text { Totally/ } \\
\text { mainly the } \\
\text { government }\end{array}$ & $\begin{array}{l}\text { Totally/mainly } \\
\text { the family }\end{array}$ & $\begin{array}{c}\text { Totally/ } \\
\text { mainly the } \\
\text { government }\end{array}$ & $\begin{array}{l}\text { Totally/mainly } \\
\text { the family }\end{array}$ & $\begin{array}{c}\text { Totally/ } \\
\text { mainly the } \\
\text { government }\end{array}$ \\
\hline Italy & 36.5 & 16.7 & 29.5 & 20.6 & 17.5 & 37.8 \\
\hline Spain & 36.6 & 20.8 & 31.4 & 23.2 & 22.2 & 34.9 \\
\hline Germany & 43.6 & 12.0 & 28.7 & 16.0 & 14.8 & 36.5 \\
\hline France & 13.3 & 48.0 & 8.7 & 53.7 & 8.4 & 50.6 \\
\hline Denmark & 4.1 & 77.7 & 2.5 & 88.8 & 3.7 & 83.1 \\
\hline \multirow[t]{3}{*}{ Netherlands } & 13.6 & 45.8 & 5.5 & 61.9 & 5.9 & 69.1 \\
\hline & \multicolumn{4}{|c|}{ Assistance for the elderly in need of care in their home } & \multicolumn{2}{|c|}{$\begin{array}{l}\text { Financial support for the } \\
\text { elderly who live below } \\
\text { subsistence level }\end{array}$} \\
\hline & \multicolumn{2}{|c|}{ Mainly the family } & \multicolumn{2}{|c|}{ Mainly society } & $\begin{array}{l}\text { Mainly the } \\
\text { family }\end{array}$ & $\begin{array}{l}\text { Mainly } \\
\text { society }\end{array}$ \\
\hline Romania & \multicolumn{2}{|c|}{45.6} & \multicolumn{2}{|c|}{5.9} & 5.6 & 26.6 \\
\hline Bulgaria & \multicolumn{2}{|c|}{18.8} & \multicolumn{2}{|c|}{6.6} & 3.8 & 29.2 \\
\hline Russia & \multicolumn{2}{|c|}{22.1} & \multicolumn{2}{|c|}{7.4} & 3.4 & 38.6 \\
\hline Norway & \multicolumn{2}{|c|}{0.6} & \multicolumn{2}{|c|}{26.3} & 0.5 & 61.9 \\
\hline
\end{tabular}

Source: for Romania, Bulgaria, Russia and Norway: GGS wave 1, conducted around 2005; for other countries: 2004 SHARE data (Fokkema et al. 2008: 37, Table 4.1) 
Tab. 7: Attitudes towards the duty of parents/grandparents to care for their children/grandchildren, selected countries, percentages per 100 respondents aged $50+$

\begin{tabular}{|c|c|c|c|c|c|c|c|c|}
\hline & \multicolumn{2}{|c|}{$\begin{array}{l}\text { To be there for their } \\
\text { grandchildren in } \\
\text { case of difficulty }\end{array}$} & \multicolumn{2}{|c|}{$\begin{array}{l}\text { To help the } \\
\text { parents of their } \\
\text { grandchildren in } \\
\text { looking after young } \\
\text { grandchildren }\end{array}$} & \multicolumn{2}{|c|}{$\begin{array}{l}\text { To do their best for } \\
\text { their children even } \\
\text { at the expense of } \\
\text { their own } \\
\text { well-being }\end{array}$} & \multicolumn{2}{|c|}{$\begin{array}{l}\text { To contribute } \\
\text { towards the } \\
\text { economic security } \\
\text { of grandchildren } \\
\text { and their family }\end{array}$} \\
\hline & $\begin{array}{l}\text { Agree/ } \\
\text { strongly } \\
\text { agree }\end{array}$ & $\begin{array}{l}\text { Disagree/ } \\
\text { strongly } \\
\text { disagree }\end{array}$ & $\begin{array}{l}\text { Agree/ } \\
\text { strongly } \\
\text { agree }\end{array}$ & $\begin{array}{l}\text { Disagree/ } \\
\text { strongly } \\
\text { disagree }\end{array}$ & $\begin{array}{l}\text { Agree/ } \\
\text { strongly } \\
\text { agree }\end{array}$ & $\begin{array}{l}\text { Disagree/ } \\
\text { strongly } \\
\text { disagree }\end{array}$ & $\begin{array}{l}\text { Agree/ } \\
\text { strongly } \\
\text { agree }\end{array}$ & $\begin{array}{c}\text { Disagree/ } \\
\text { strongly } \\
\text { disagree }\end{array}$ \\
\hline Italy & 89.6 & 3.3 & 77.8 & 7.1 & 88.6 & 3.4 & 63.7 & 13.4 \\
\hline Spain & 87.1 & 2.6 & 69.1 & 10.9 & 89.8 & 2.8 & 58.0 & 14.4 \\
\hline Germany & 83.5 & 3.2 & 74.8 & 7.4 & 58.3 & 21.2 & 39.8 & 27.9 \\
\hline France & 89.3 & 2.9 & 69.4 & 9.7 & 72.0 & 10.7 & 49.4 & 17.5 \\
\hline Denmark & 76.0 & 10.2 & 37.5 & 34.3 & 70.2 & 13.6 & 17.0 & 50.8 \\
\hline \multirow[t]{3}{*}{ Netherlands } & 74.0 & 10.7 & 28.5 & 42.0 & 64.9 & 14.9 & 25.1 & 43.2 \\
\hline & \multicolumn{4}{|c|}{$\begin{array}{l}\text { Grandparents should look } \\
\text { after their grandchildren if the } \\
\text { parents of these grandchildren } \\
\text { are unable to do so }\end{array}$} & \multicolumn{2}{|c|}{$\begin{array}{l}\text { If their adult } \\
\text { children are in } \\
\text { need, parents } \\
\text { should adjust their } \\
\text { own lives in order } \\
\text { to help them }\end{array}$} & \multicolumn{2}{|c|}{$\begin{array}{l}\text { Parents ought to } \\
\text { provide financial } \\
\text { help to their adult } \\
\text { children when the } \\
\text { children are having } \\
\text { financial difficulties }\end{array}$} \\
\hline & \multicolumn{2}{|c|}{$\begin{array}{c}\text { Agree/ } \\
\text { strongly agree }\end{array}$} & \multicolumn{2}{|c|}{$\begin{array}{c}\text { Disagree/ } \\
\text { strongly disagree }\end{array}$} & $\begin{array}{l}\text { Agree/ } \\
\text { strongly } \\
\text { agree }\end{array}$ & $\begin{array}{l}\text { Disagree/ } \\
\text { strongly } \\
\text { disagree }\end{array}$ & $\begin{array}{l}\text { Agree/ } \\
\text { strongly } \\
\text { agree }\end{array}$ & $\begin{array}{c}\text { Disagree/ } \\
\text { strongly } \\
\text { disagree }\end{array}$ \\
\hline Romania & \multicolumn{2}{|c|}{79.9} & \multicolumn{2}{|c|}{3.4} & 47.1 & 18.7 & 74.4 & 4.0 \\
\hline Bulgaria & \multicolumn{2}{|c|}{76.8} & \multicolumn{2}{|c|}{7.1} & 51.2 & 17.1 & 68.1 & 7.4 \\
\hline Russia & \multicolumn{2}{|c|}{79.1} & \multicolumn{2}{|c|}{7.2} & 64.4 & 11.8 & 72.7 & 6.4 \\
\hline Norway & \multicolumn{2}{|c|}{50.9} & \multicolumn{2}{|c|}{15.8} & 23.6 & 40.5 & 42.6 & 19.2 \\
\hline
\end{tabular}

Source: for Romania, Bulgaria, Russia and Norway: GGS wave 1, conducted around 2005; for other countries: 2004 SHARE data (Fokkema et al. 2008: 38, Table 4.2)

adult children face economic difficulties. Elderly people in Romania, however, show a much lower level of agreement in terms of adapting their own lives to the urgent needs of their adult children (Table 7).

In a comparative perspective, Romania shows trends that are much more similar to those observed in Southern Europe than in other countries. In Italy and Spain, as in Romania, the responsibility of caring for the elderly lies primarily with their families, while the government is only considered responsible in situations where the family cannot fulfil these duties, primarily in terms of financial assistance (Table 6). In all countries, the sense of duty on the part of older adults towards their children or their grandchildren is strong. Romanians, however, feel they are responsible for the financial security of their adult children and are willing to adjust their lives in order to be able to help them - this pattern resembles the one observed in Bulgaria and Russia (though at a higher and lower degree than in Southern European countries, respectively) (Table 7). 
In conclusion, a comparison of attitudes towards family care obligations reveals that Romanian opinion are quite similar to Italian or Spanish views, especially when it comes to caring for elderly parents or caring for grandchildren when adult children find themselves in times of hardship. Western and Northern European countries hold quite different views.

\section{Discussion and conclusion}

In this paper, we explore whether the family system in Romania can be considered as a pattern of strong family ties similar to that of Southern European countries. To this end, we compare Romania to countries from different regions of Europe.

We observe a number of similarities between Romania and Southern Europe in terms of behaviours reflecting "strong family ties": a high proportion of children who only leave the parental home to marry, few individuals who live alone, a low but increasing level of non-marital cohabitation, a relatively high proportion of elderly people living with their children or other relatives and a low proportion living in institutions. Attitudes on family care obligations are similar to those observed in Southern European countries. In these countries, emphasis is placed on the role of the family, as opposed to the larger society, in terms of providing mutual intergenerational support.

Although on the rise, the age at leaving the parental home is lower in Romania than in South Europe. Moreover, co-residence of young married couples and their parents is more frequent. According to our assessment, it is not different kinds of family ties that enhance this variance, but rather economic constraints and the difficult housing situation in Romania. The collapse of the communist regime marked a changing point in family life and the life course of young adults. Parents who experienced important life course events during the communist regime wish to provide similarly smooth transitions for their children; the support once received from the state (especially for housing) is now replaced by family contributions. In this respect, family ties might have become more important since the fall of the socialist regime.

More generally, we consider whether and how decades of socialist government affected local cultures and changed family systems. Ultimately, we agree with Alain Blum (2001), who argues that socialist regimes were too distant from everyday life and thus unable to adapt themselves to the social contexts they wanted to dominate. Consequently, they did not extensively or sustainably modify family systems. More precisely, while they may have facilitated temporary adaptations, they did not alter underlying cultural and behavioural models. Danaj et al. (2005) reach the same conclusions for Albania.

Although the behaviour observed in Romania is associated with the strong family ties characteristic of Southern European countries, the question still remains as to how close these similarities truly are, i.e. whether they are deep-rooted or only temporary. Both regions appear to be experiencing the changes in living arrangements and union formation typically associated with the path towards the Second 
Demographic Transition (SDT). The increasing acceptance of new behaviours and a growing proportion of non-marital cohabitations, non-marital births, and divorces (not discussed in this paper) are often considered as indicators of progress in the SDT. One might therefore ask: Are strong family ties in this regard simply a residual pattern of traditional behaviours, delaying the general path of the SDT, or a sign that countries with strong family ties follow different paths and time schedules?

Related to this debate, Thornton and Philipov (2009) propose a developmental idealism framework for explaining recent changes in marital and fertility behaviour in Eastern Europe. Within their paradigm, Western European and North American countries are considered as very modern and developed, so that they also have the power to affect (among others things) beliefs, values and behaviours about marriage and fertility in regions such as Eastern Europe. Along these lines, they suggest that more "traditional" populations have increased their tolerance regarding different family values and behaviour. Although Thornton and Philipov (2009: 146, 150) do not specifically consider family ties, they state that "it is also possible that [...] the confidence and authority of parents declined, providing many more alternatives for young adults", and that "it would also have been difficult [...] for parents to maintain their influence on their children's beliefs, values, and behaviour". Furthermore, it is possible that some demographic changes, such as the increase in divorce or the diffusion of step-families, have weakened family ties as well. The SDT has not, however, followed the same pattern everywhere. It is possible that this transition may follow specific paths or time schedules in countries with strong family ties. Potârcă et al. (2013) show that in Romania, strong norms about marriage and family shape the SDT pattern in a similar manner as observed in many Southern European countries. Lesthaeghe (2010) also acknowledges that although the SDT now concerns most European populations, local narratives may affect changes in values and new behaviours, and thus the SDT may differ by context. Even Reher (1998: 221) emphasizes historical, cultural, geographical and social continuity, stressing that modernisation cannot erase "the deep disparities that have always characterized the family in the different regions and cultures in Europe".

At the conclusion of this comparative analysis, many questions remain and warrant further investigation. One of the primary difficulties we encountered was a lack of available comparable data and indicators for Romania and other European countries. Occasionally, similar (but not identical) indicators are utilised across surveys, making it difficult to draw reliable conclusions. Comparative datasets have often been developed within different theoretical frameworks. In fact, the GGS programme was developed within the framework of the SDT, while the SHARE project is more focused on intergenerational solidarity, and Eastern European countries and the Balkans are not yet well represented. This article can serve as a basis for future comparative studies and progress towards a more comprehensive framework for understanding social and demographic similarities and differences within Europe.

This study does not take into account another demographic trend that has deeply affected Romania in recent years, namely a very relevant out-migration (UN Population Division 2013). Out-migration can weaken family networks both in the native as well as the host country. However, it remains uncertain to what extent such move- 
ments affect family ties, and empirical evidence is currently insufficient to examine the issue. In our opinion, out-migration will not significantly reduce family ties, at least in the short run, thanks to strong migration chains and support of migrants within extended families - families who provide support to both those within Romania who do not migrate as well as those within the host country who do migrate. Unfortunately, this cannot be tested in the host countries because of a lack data. However, there is one (relatively weak) indicator that might illustrate such support: assistance in finding employment in the host country. For example, 76 percent of Romanians living in Italy found work with the help of relatives or friends, compared to 72 percent of the entire group of foreign citizens (/stat 2009). Other studies point to the relevance of continuity in migrants' behaviours and attitudes in native and host countries: see, for example, Khoo et al. (2002) on cohabitation among Italians who were raised in Australia, and Carl (2013) on gender role attitudes among firstand second-generation immigrants in Europe. Does this hold for family ties among Romanian migrants as well? Future research might address this question.

This paper considers each country as a homogeneous entity. Average behaviours may, however, conceal internal differences. We know, for example, that the socialist regime in Romania strongly shaped a process of urbanisation with differences in family-related behaviour in urban and rural areas (see Section 2), and that the Romanian population is composed of numerous ethnic groups (Hărăguș 2009; Rada 2013). Differences in family ties among sub-populations thus remain unexplored, and more insights into this issue could shed new light on the persistence and dynamics of family ties in Romania. ${ }^{8}$

Notwithstanding these important questions, in light of the literature, and the comparison of certain demographic behaviours and values discussed in this paper, we can give a positive answer to the question initially posed: Does Romania exhibit a pattern of strong family ties? This conclusion may also apply to other post socialist European countries, although it is not, in our opinion, a common trait to this region as a whole. These results encourage a broadening of our view towards all European countries, pushing us to see if the line from the Pyrenees to the Alps, dividing Southern Europe with strong family ties from North-Western Europe with weak family ties, can be lengthened to the Carpathians and shed new light on commonalities and differences in other demographic behaviours.

\section{Funding}

Research for this paper was made possible by funding from the European Union's Seventh Framework Programme (FP7/2007-2013) under grant agreement no. 320116 for the research project FamiliesAndSocieties.

8 Differences in family related behaviours have been observed between urban and rural areas and ethnic groups also in Albania (Hemming et al. 2012). 


\section{References}

Aassve, Arnstein et al. 2007: Does leaving home make you poor? Evidence from 13 European countries. In: European Journal of Population 23,3-4: 315-338 [doi: 10.1007/ s10680-007-9135-5].

Ahmed, Patricia; Emigh, Rebecca Jean 2005: Household Composition in PostSocialist Eastern Europe. In: International Journal of Sociology and Social Policy 25: 9-41 [doi: 10.1108/01443330510791117].

Alber, Jens; Köhler, Ulrich 2004: Health and care in an enlarged Europe. European Foundation for the Improvement of Living and Working Conditions. Luxembourg: Office for Official Publications of the European Communities.

Bezrukof, Vladislav; Foigt, Natalia 2002: Political, social and economic crises and living arrangements of older persons: the case of Ukraine. New York: UN Population Division.

Billari, Francesco C.; Philipov, Dimiter; Baizàn Pau 2001: Leaving home in Europe: The experience of cohorts born around 1960. In: International Journal of Population Geography 7: 339-356 [doi: 10.1002/ijpg.231].

Billari, Francesco C.; Liefbroer, Aart C. 2010: Towards a new pattern of transition to adulthood? In: Advances in Life Course Research 15: 59-75 [doi:10.1016/j.alcr.2010.10.003].

Blum, Alain 2001: Socialist families? In: Barbagli, Marzio; Kertzer, David (Eds.): Family life in the twentieth century. New Haven: Yale University Press.

Carl, Noah 2013: Gender role attitudes among European immigrants. Paper presented at the FamChIP Conference "Comparing families: does international perspective help?" Warsaw, December 17-18th, 2013.

Dalla Zuanna, Gianpiero 2001: The Banquet of Aeolus. A familistic interpretation of Italy's lowest low fertility. In: Demographic Research 4: 136-162 [doi: 10.4054/ DemRes.2001.4.5].

Dalla Zuanna, Gianpiero; Michielin, Francesca; Bordignon, Fabio 2007: Proximity between adult children and their mothers: A European comparison. Paper presented at the Workshop "Changes in leaving arrangements and family relationships in the context of strong family ties. Southern Europe and Eastern Asia: trends, causes and consequences". Rostock, April 20-21, 2007.

Dan, Adrian 1996: Aspecte ale politicii locuirii în România şi alte ţări foste socialiste [Elements of housing policy in Romania and other ex-socialist countries]. In: Calitatea Vieţii 3-4: 217-236.

Dan, Adrian 2009: Locuinta si serviciile de locuire [Housing]. In: Preda, Marian (Ed.): Riscuri si inechitati sociale in Romania [Risks and social inequities in Romania]. Iasi: Polirom.

Danaj, Ermira et al. 2005: Youth integration in the Albanian society. 2nd Conference on Young people and societies in Europe and around the Mediterranean. Marseilles, 2426 October 2005.

De Jong Gierveld, Jenny; De Valk, Helga; Blommesteijn, Marieke 2002: Living Arrangements of Older Persons and Family Support in More Developed Countries. In: Population Bulletin of the United Nations 42-43: 193-217.

De Jong Gierveld, Jenny; Dykstra, Pearl A.; Schenk, Niels 2012: Living arrangements, intergenerational support types and older adult loneliness in Eastern and Western Europe. In: Demographic Research 27: 167-200 [doi: 10.4054/DemRes.2012.27.7]. 
De Vos, Susan; Sandefur, Gary 2002: Elderly Living Arrangements in Bulgaria, The Czech Republic, Estonia, Finland, and Romania. In: European Journal of Population 18,1: 21-38 [doi: 10.1023/A:1013877606584].

Engelen, Theo; Wolf, Arthur (Eds.) 2005: Marriage and family in Eurasia: Perspectives on the Hajnal hypothesis. Amsterdam: Aksant Academic.

European Commission 2012: EU Youth Report. Commission Staff Working Document. Status of the situation of young people in the European Union [http://ec.europa.eu/ youth/policy/implementation/report_en.htm, 14.02.2016].

Eurostat 2009: Youth in Europe. A statistical portrait [http://eapyouth.eu/sites/default/ files/documents/eurostat_2009_report.pdf, 14.02.2016].

Ferge, Zsuzsa 1997: The Perils of the Welfare State's Withdrawal. In: Social Research 64,4: 1381-1402.

Fokkema, Tineke; Liefbroer, Aart C. 2008: Trends in living arrangements in Europe: Convergence or divergence? In: Demographic Research 19: 1351-1418 [doi: 10.4054/ DemRes.2008.19.36].

Fokkema, Tineke; Ter Bekke, Susan; Dykstra, Pearl A. 2008: Solidarity between parents and their adult children in Europe. Amsterdam: Knaw Press.

Genov, Nikolai 1998: Transformation and anomie: problems of quality of life in Bulgaria. In: Social Indicator Research 43: 197-209 [doi: 10.1023/A:1006895413626].

Ghodsee, Kristen; Bernardi, Laura 2012: Starting a Family at Your Parents' House: Multigenerational Households and Below Replacement Fertility in Urban Bulgaria. In: Journal of Comparative Family Studies 43: 439-459.

Hajnal, John 1965: European marriage patterns in perspective. In: Glass, David Victor; Eversley, David Edward Charles (Eds.): Population in History. Essays in Historical Demography. London: Edward Arnold: 101-143.

Hajnal, John 1982: Two kinds of preindustrial household formation system. In: Population and Development Review 8: 449-494.

Hank, Karsten 2007: Proximity and contact between older parents and their children. A European comparison. In: Journal of Marriage and Family 69,1: 159-173 [doi: 10.1111/j.1741-3737.2006.00351.x].

Hărăguş, Mihaela 2008: Tranzitia la statutul de parinte in Europa. Evolutii recente si posibili determinanti. Cluj-Napoca: Editura Presa Universitară Clujeană.

Hărăguş, Mihaela 2009: Different Reproductive Patterns in Romania: An Urban-Rural Comparison. In: Fauve-Chamoux, Antoinette; Bolovan, loan (Eds.): Families in Europe between the 19th and the 21st Centuries. From Traditional Model to Contemporary PACS. Cluj-Napoca: Editura Presa Universitară Clujeană: 417-433.

Hărăguş, Mihaela 2010: Nonmarital Childbearing in Romania. In: Romanian Journal of Population Studies IV: 44-64.

Hemming, Andreas; Kera, Gentiana; Pandelejmoni, Enriketa (Eds.) 2012: Albania. Family, society and culture in the 20th century. LIT Verlag.

Hoem, Jan M. et al. 2009: Traces of the Second Demographic Transition in Four Selected Countries in Central and Eastern Europe: Union Formation as a Demographic Manifestation. In: European Journal of Population 25: 239-255 [doi: 10.1007/s10680009-9177-y].

Hoem, Jan M. et al. 2010: Levels of recent union formation: Six European countries compared. In: Demographic Research 22: 199-210 [doi: 10.4054/DemRes.2010.22.9]. 
Iacovou, Maria 2000a: Health, wealth and progeny: Explaining the living arrangements of older European women. ISER Working Papers Series 2000-8. Institute for Social and Economic Research: Essex University [https://www.iser.essex.ac.uk/publications/ working-papers/iser/2000-08.pdf, 06.01.2016].

lacovou, Maria 2000b: The living arrangements of elderly Europeans. ISER Working Papers Series 2000-9. Institute for Social and Economic Research: Essex University [https://www.iser.essex.ac.uk/publications/working-papers/iser/2000-09.pdf, 06.01.2016].

lacovou, Maria 2001: Leaving Home in the European Union. ISER Working Papers Series 2001-18 [https://www.iser.essex.ac.uk/files/iser_working_papers/2001-18.pdf, 06.01.2016]

lacovou, Maria 2011: Leaving Home: Independence, togetherness and income in Europe. United Nations, Department of Economic and Social Affairs, Population Division. Expert Paper No. 2011/10.

lacovou, Maria; Skew, Alexandra J. 2011: Household composition across the new Europe: Where do the new Member States fit in? In: Demographic Research 25: 465-490 [doi: 10.4054/DemRes.2011.25.14]

Inglot, Tomasz; Szikra, Dorottya; Rat, Cristina 2011: Continuity and Change in Family Policies of the New European Democracies. National Council for Eurasian and East European Research. [http://www.ucis.pitt.edu/nceeer/2011_825-10_Inglot1.pdf, 06.01.2016]

Isengard, Bettina; Szydlik, Marc 2012: Living Apart (or) Together? Coresidence of Elderly Parents and Their Adult Children in Europe. In: Research on Aging 34,4: 449-474 [doi: 10.1177/0164027511428455].

ISTAT (National Institute of Statistics) 2009: L'integrazione nel lavoro degli stranieri e dei naturalizzati italiani [Work integration of foreign people and new Italian citizens]. Approfondimenti, 14 dicembre 2009. Rome: Istat.

Kaser, Karl 1996: Introduction: Household and family contexts in the Balkans. In: The History of the Family 1: 375-386.

Kerblay, Basile 1985: Famille socialiste. In Burguière, André et al. (Eds.): Histoire de la Famille. Paris: A. Colin: 563-605.

Khoo, Siew-Ean; McDonald, Peter; Giorgias, Dimi; Birrel, Bob 2002: Second generation Australians. Australian Centre of Population Research and the Department of Immigration and Multicultural and Indigenous Affairs. Canberra, Australia.

Kohli, Martin; Künemund, Harald; Lüdicke, Jörg 2005: Family structure, proximity and contact. Chapter 4.1 of the SHARE First Results Book.

Kok, Jan 2009: Family Systems as frameworks for understanding variation in extra-marital births, Europe 1900-2000. In: Fauve-Chamoux, Antoinette; Bolovan, Ioan (Eds.): Families in Europe between the 19th and the 21st Centuries. From Traditional Model to Contemporary PACS. Cluj-Napoca: Presa Universitara Clujeana: 13-38.

Laslett, Peter 1983: Family and household as work group and kin group: areas of traditional Europe compared. In: Wall, Richard et al. (Eds.): Family forms in Historic Europe. Cambridge: Cambridge University Press.

Lesthaeghe, Ron 2010: The Unfolding Story of the Second Demographic Transition. In: Population and Development Review 36: 211-251 [doi: 10.1111/j.17284457.2010.00328.x]. 
Lyberaki, Antigone; Tinios, Platon 2005: Poverty and social exclusion: A new approach to an old issue. In: Börsch-Supan, Axe/ et al. (Eds.): Ageing and Retirement in Europe: First results from the Survey of Health, Ageing and Retirement in Europe. Mannheim: MEA: 302-309.

Mandic, Srna 2008: Home-Leaving and its Structural Determinants in Western and Eastern Europe: An Exploratory Study. In: Housing Studies 23: 615-636 [doi: 10.1080/02673030802112754].

Manning, Nick 2004: Diversity and change in pre-accession Central and Eastern Europe since 1989. In: Journal of European Social Policy 14,3: 211-232 [doi: 10.1177/0958928704044620].

Massino, Jill 2010: Something old, something new. Marital role and relations in state socialist Romania. In: Journal of Women's History 22: 34-60 [doi: 10.1353/jowh.0.0132].

Micheli, Giuseppe A. 2000: Kinship, family and social network: The anthropological embedment of fertility change in southern Europe. In: Dalla Zuanna, Gianpiero; Micheli, Giuseppe (Eds.): Strong family and low fertility: a paradox? New perspective in interpreting contemporary family and reproductive behaviour. Dordrecht: Kluwer Academic Publishers: 77-104.

Mureşan, Cornelia 2007: Family and fertility in Romania pre- and post-transition: a lifetable description. MPIDR Working Paper 2007-018.

Mureşan, Cornelia et al. 2008: Romania: Childbearing metamorphosis within a changing context. In: Demographic Research 19: 855-906 [doi: 10.4054/DemRes.2008.19.23].

Mureşan, Cornelia 2012a: Schimbările comportamentului familial în România. O abordare din perspectiva cursului vieții [Family change in Romania. A life course approach]. Cluj-Napoca: Presa Universitară Clujeană.

Mureşan, Cornelia 2012b: Schimbarea structurilor familiale și slăbirea solidarității familiale [The change of family structures and the weakening of family solidarity]. In: $\mathrm{Mu}$ reşan, Cornelia (Ed.): Situația vârstnicilor din România [The situation of the elderly in Romania]. Cluj-Napoca: Presa Universitară Clujeană: 79-90.

Oaneş-Faludi, Cristina; Hărăguş, Mihaela 2009: The Growth in Non-Marital Fertility and Other Related Behaviours in Romania after 1989. In: Romanian Journal of Population Studies III: 45-71.

Palloni, Alberto 2000: Living Arrangements of Older Persons. CDE Working Paper No. 000-02. Center for Demography and Ecology. University of Wisconsin-Madison.

Perelli-Harris, Brienna et al. 2012: Changes in union status during the transition to parenthood in eleven European countries, 1970s to early 2000s. In: Population Studies 66: 167-182 [doi: 10.1080/00324728.2012.673004].

Plakans, Andrejs; Wetherell, Charles 2005: The Hajnal line and Eastern Europe. In: Engelen, Theo; Wolf, Arthur (Eds.): Marriage and the family in Eurasia: Perspectives on the Hajnal hypothesis. Amsterdam: Aksant Academic: 105-28.

Popescu, Livia 2004: Politicile sociale est-europene între paternalism de stat şi responsabilitate individuală, Cluj: Presa Universitară Clujeană.

Potârcă, Gina; Mills, Melinda; Lesnard, Laurent 2013: Family Formation Trajectories in Romania, the Russian Federation and France: Towardsteh Second Demographic Transition? In: European Journal of Population 29: 69-101 [doi: 10.1007/s10680-012-9279-9]. 
Rada, Cornelia 2013: Valori identitare ale familiei româneşti contemporane în contextul globalizării. O abordare antropologică [Romanian family identity values in the context of globalization. An anthropological approach]. Editura Muzeului Național al Literaturii Române.

Reher, David Sven 1998: Family Ties in Western Europe: Persistent Contrasts. In: Population and Development Review 24: 203-234.

Robila, Mihaela 2004: Families in Eastern Europe: Context, Trends and Variations. In: Robila, Mihaela (Ed.): Families in Eastern Europe. Amsterdam: Elsevier: 1-14.

Rotariu, Traian 2009: Marital and Extramarital Fertility in Latter-Day Romania. In: FauveChamoux, Antoinette; Bolovan, loan (Eds.): Families in Europe between the 19th and the 21st Centuries. From Traditional Model to Contemporary PACS. Cluj-Napoca: Presa Universitara Clujeana: 361-380.

Rotariu, Traian et al. 2012: Căsătoria şi reproducerea populaţiei. In: Rotariu, Traian; Vouneag, Virgil (Eds.): Inerţie şi schimbare. Dimensiuni sociale ale tranziţiei în România. Polirom: laşi: 125-160.

Santarelli, Elisabetta; Cottone, Francesco 2009: Leaving home, family support and intergenerational ties in Italy: Some regional differences. In: Demographic Research 21: 1-22 [doi: 10.4054/DemRes.2009.21.1].

Saraceno, Chiara; Olagnero, Manuela; Torrioni, Paola 2005: First European Quality of Life Survey: Families, Work and Social Networks. Luxembourg: European Foundation for the Improvement of Living and Working Conditions.

Speder, Zsolt 2005: Diversity of family structure in Europe. Paper presented at IUSSP Conference. Tours, France.

Thornton, Arnald; Philipov, Dimiter 2009: Sweeping Changes in Marriage, Cohabitation and Childbearing in Central and Eastern Europe: New Insights from the Developmental Idealism Framework. In: European Journal of Population 25: 123-156 [doi: 10.1007/ s10680-009-9181-2].

Todorova, Maria 1996: Situating the family of Ottoman Bulgaria within the European pattern. In: The History of the Family 1: 443-460.

Tomassini, Cecilia et al. 2004: Living arrangements among older people: an overview of trends in Europe and the USA. In: Population trends 115, spring 2004.

UEFISCDI - CNFIS 2014: Raport public anual - 2013 Starea finanțării învățământului superior și măsurile de optimizare ce se impun [Yearly Public Report - 2013 The state of funding in the superior education and required optimization measures] [http://www. cnfis.ro/wp-content/uploads/2012/08/CNFIS-Raport-public2013-final.pdf, 14.02.2016].

UN (United Nations, Population Division) 2013: World Population Prospects: The 2012 Revision, Highlights and Advance Tables. ESA/P/WP.228. New York: United Nations. 
Maria Castiglioni $(\bowtie)$. Dept. of Statistical Sciences, University of Padova. Italy. E-mail: casti@stat.unipd.it

URL: http://homes.stat.unipd.it/mariacastiglioni/en/content/home

Mihaela Hărăguş. Centre for Population Studies, Babes-Bolyai University, Cluj-Napoca. Romania.E-mail: mihaela.haragus@ubbcluj.ro

URL: http://centre.ubbcluj.ro/csp/mihaela_haragus.html

Cristina Faludi, Paul Teodor Hărăguş. Babes-Bolyai University, Cluj-Napoca, Faculty of Sociology and Social Work. Romania.

E-mail: cristina.faludi@socasis.ubbcluj.ro,tpharagus@socasis.ubbcluj.ro

URL: http://socasis.ubbcluj.ro/en/index.php?option=com_content\&view=article\&id=4 \&ltemid $=5$ 


\section{Comparative Population Studies}

WWW.comparativepopulationstudies.de

ISSN: 1869-8980 (Print) - 1869-8999 (Internet)

Published by

Prof. Dr. Norbert F. Schneider

Federal Institute for Population Research

D-65180 Wiesbaden / Germany

\section{(cc) BY-SA}

2016

\section{Managing Editor}

Frank Swiaczny

\section{Assistant Managing Editor}

Katrin Schiefer

\section{Copy Editor}

(Selected Articles in German)

Dr. Evelyn Grünheid

\section{Layout}

Beatriz Feiler-Fuchs

E-mail:cpos@bib.bund.de

\section{Scientific Advisory Board}

Paul Gans (Mannheim)

Karsten Hank (Köln)

Johannes Huinink (Bremen)

Michaela Kreyenfeld (Rostock)

Marc Luy (Wien)

Notburga Ott (Bochum)

Peter Preisendörfer (Mainz)

Nikola Sander (Groningen)

Zsolt Spéder (Budapest)

\section{Board of Reviewers}

Martin Abraham (Erlangen)

Laura Bernardi (Lausanne)

Hansjörg Bucher (Bonn)

Claudia Diehl (Konstanz)

Andreas Diekmann (Zürich)

Gabriele Doblhammer-Reiter (Rostock)

Jürgen Dorbritz (Wiesbaden)

Anette Eva Fasang (Berlin)

E.-Jürgen Flöthmann (Bielefeld)

Alexia Fürnkranz-Prskawetz (Wien)

Beat Fux (Salzburg)

Joshua Goldstein (Berkeley)

Sonja Haug (Regensburg)

Hill Kulu (Liverpool)

Aart C. Liefbroer (Den Haag)

Kurt Lüscher (Konstanz)

Emma Lundholm (Umeå)

Nadja Milewski (Rostock)

Dimiter Philipov (Wien)

Roland Rau (Rostock)

Tomáš Sobotka (Wien) Jeroen Spijker (Barcelona)

Olivier Thévenon (Paris)

Helga de Valk (Brussel)

Heike Trappe (Rostock)

Michael Wagner (Köln) 